Article

\title{
Impact of COVID-19 on Mergers, Acquisitions \& Corporate Restructurings
}

\author{
Chokri Kooli ${ }^{1, *(1)}$ and Melanie Lock Son ${ }^{2}$ \\ 1 College of Commerce and Business, Lusail University, Zone 69, St 100, Building 333, Lusail, \\ Doha 122104, Qatar \\ 2 University of Ottawa, Ottawa, ON K1N 6N5, Canada; mlock012@uottawa.ca \\ * Correspondence: ibm4chk@yahoo.fr
}

check for updates

Citation: Kooli, C.; Lock Son, M. Impact of COVID-19 on Mergers, Acquisitions \& Corporate Restructurings. Businesses 2021, 1, 102-114. https://doi.org/10.3390/ businesses 1020008

Academic Editor: Cristina Raluca Gh. Popescu

Received: 16 July 2021

Accepted: 10 August 2021

Published: 16 August 2021

Publisher's Note: MDPI stays neutral with regard to jurisdictional claims in published maps and institutional affiliations.

Copyright: (c) 2021 by the authors. Licensee MDPI, Basel, Switzerland. This article is an open access article distributed under the terms and conditions of the Creative Commons Attribution (CC BY) license (https:/ / creativecommons.org/licenses/by/ $4.0 /)$.

\begin{abstract}
Most economic downturns have stemmed from inefficiencies in the economic system. This research paper aims at investigating the impact of the COVID-19 pandemic - an exogeneous health crisis-on global mergers and acquisition (M\&A) activity. By gathering statistical data about global transaction volume, value, and type, the study aims at getting a pulse of how mergers, acquisitions, and other restructuring activities have been utilized to support corporate objectives amidst these unprecedented times. While the full-fledged impact of COVID-19 cannot be fully captured at the moment (early 2021), the study attempts to illustrate how this change to economic stability caused a Schumpeterian creative destruction of industries. As firms prepare for the growth that will follow this downturn, M\&A will enable companies to look into a future infused with technology and structurally different business models. This research paper thus captures the deliberate transformation occurring in the deal world to discuss the possible outlook of the M\&A deal market in the post-pandemic world.
\end{abstract}

Keywords: mergers and acquisitions; COVID-19; economic stability; post-pandemic; corporate restructurings

\section{Introduction}

While many were speculating about an economic downturn in 2020 (following a bull market), no one foresaw the economic shocks that would be brought by the onset of a pandemic. The COVID-19 pandemic halted most corporate operations and locked most of the world's population inside their homes for health and safety purposes. The lack of precedence and preparedness of companies (big or small) to face such exogenous events has resulted in organization-environment fit/misfits [1,2]. The juggling act of complying with new sanitation standards, government restrictions [3,4], and supply and demand constraints have exposed firms' capacity to face the new business environment shaped by the health crisis. In this novel environment, mergers, acquisitions, and corporate restructurings have become key considerations for companies looking to realign their strategic plans to better compete, let alone survive.

One year into the pandemic, we can see that similar to most economic downturns, some companies were fortunate to profit from the weakening economy while other companies were forced into survival mode or to cease operations. On the one hand, we have companies with strong balance sheets that used the misfortune of COVID-19 as an opportunity to future-proof and diversify their portfolio using mergers or acquisitions. On the other hand, some companies were forced to divest part of their business to remove the excess dead weight. Regardless of the strategy undertaken by corporations, CFOs were faced with major hurdles in forecasting cash flow and performing accurate valuation given the unpredictability of the pandemic.

While globally the M\&A market slowed down, it never came to a zero-deal volume. The pandemic was a surprise that tested the resilience of companies in the context of an 
interconnected world. This paper thus explores the impact of COVID-19 on global mergers, acquisitions, and corporate restructuring activities. Using scientific literature as well as interviews and statistical data collected by global institutions, the paper looks into better understanding the short- and long-term effects that this unprecedented turn of events has had on global M\&A.

Throughout this research paper, the term M\&A is used to refer to the financial transaction by which two or more different entities consolidate in view of creating synergies that can be exemplified by gains in operational efficiency and/or increased capabilities. More particularly, the term "mergers" entails the joining of two comparable sized companies in view of creating a new entity, while the term "acquisitions" describes the absorption of a company by a (typically) larger one. While all M\&A proceedings are all unique in value and type, they all aim at supporting the strategic mission and vision of the parties involved.

In the first part of the paper, through a descriptive statistical analysis of the M\&A markets, we aim to get a pulse of how M\&A proceeded amidst the COVID-19 pandemic. The second part then assesses the impact that the health hazard has had on the strategic plans of companies, and how mergers, acquisitions, or other corporate restructuring activities have been utilized as a value creation tool to complement the changes in corporate focus. This section also includes an analysis of ways in which the pandemic has altered the M\&A process. In the third part of the paper, there is an analysis of other exogenous factors that have also incentivized M\&A activity amidst uncertain times. Additionally, in the fourth section, the research discusses trends that are going to shape M\&A activity in the post-pandemic world. Finally, the authors offer their outlook of the M\&A market as countries globally recover and adapt to the altered consumer and organizational behaviors.

\section{Materials and Methods}

By gathering statistical data about global transaction volume, value, and type, the study aims at getting a pulse of how mergers, acquisitions, and other restructuring activities have been utilized to support corporate objectives amidst those unprecedented times.

\section{Results}

\subsection{MEA during the COVID-19 Pandemic}

\section{Deal Volume in the Different Waves of the Pandemic}

As observed in Figure 1, when the World Health Organization declared a world outbreak, the global volume of M\&A deals experienced a sharp decline of about $50 \%$ as of mid-February 2020. The unpredictable business environment characterized by stay-athome orders, competing for new government policies, and unclear projections of the scale of the COVID-19 virus caused this sharp downward slope [5]. In the following months, the slow easing of lockdown measures, as well as vaccine announcements, gave momentum to M\&A proceedings. Therefore, in those unprecedented times, the total value of disclosed deals from January 2020 to October 2020 amounted to a value of USD 2.2 trillion [6].

In the last two quarters of 2020, in addition to the reduction in the virus-inflicted uncertainty, hope for geopolitical stability following a Biden-Harris win and the willingness of financiers to make up for lost time at the beginning of the year led to V-shape recovery for the deal market. The fourth quarter of 2020 was designated the "third strongest for M\&A in two decades." According to the Financial Times, "since the start of October, \$612bn of deals have been agreed, up from \$461bn during the same period in 2019 and \$491bn in 2018" [7]. 


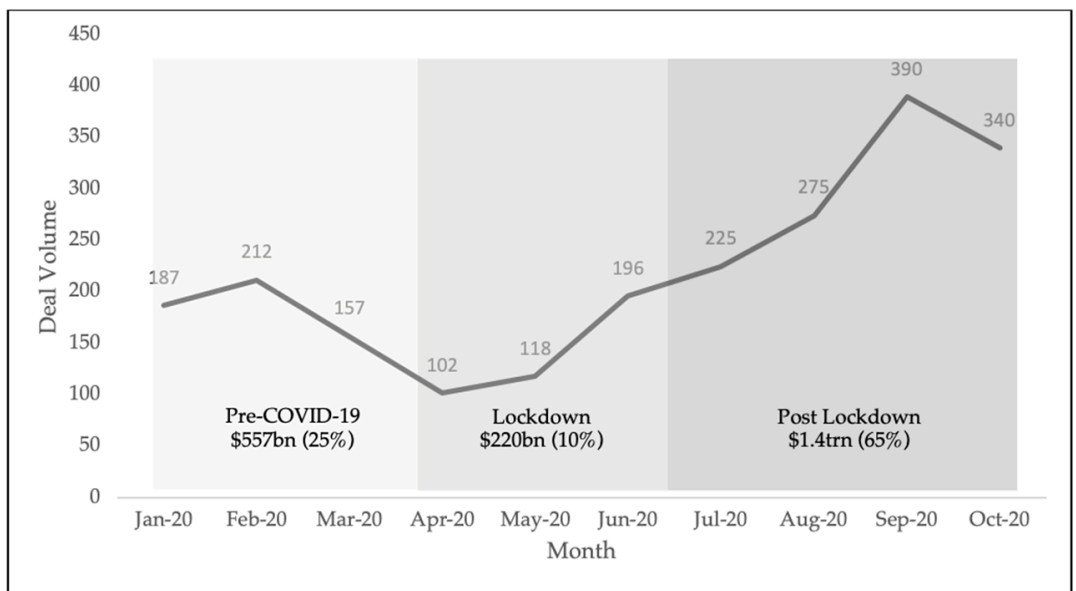

Figure 1. Deal Volume: Breakdown by Phases (Source: Data collected from Deloitte).

\section{Deal by Industry}

Compared to previous economic downturns that stemmed from the financial system itself, the 2020 economic crisis was a global health tragedy intertwined with supply and demand suppressions. As such, its impact has been non-uniform on the different industries. Shortages of toilet paper on store shelves, the rapid adoption of telehealth, and limited longhaul travel are illustrations of how the pandemic has deeply altered consumer behavior. Through the "valley of death" of the pandemic [8], a new normal is emerging. Industries that were once resilient and considered essential may no longer be considered so and they are being challenged by new business models. Consequently, "we're currently in a period of unprecedented accelerated Schumpeterian Creative Destruction" [8].

In light of those transitions, as indicated in Figure 2, we can see that the industries least impacted by COVID-19-those that were either considered "essential" or those that were able to rapidly adapt to the new normal-were more active in the M\&A sphere. For instance, the technology and healthcare sectors saw strong adoption during the crisis and outperformed their historical average number of deals as companies continued to grow organically through M\&A. However, many industries that were historically resilient with strong M\&A deal volumes were affected by restrictions brought by the pandemic. They experienced a lower M\&A deal volume in 2020. Therefore, the predictability and outlook of the industries were crucial factors that determined the M\&A playbook.

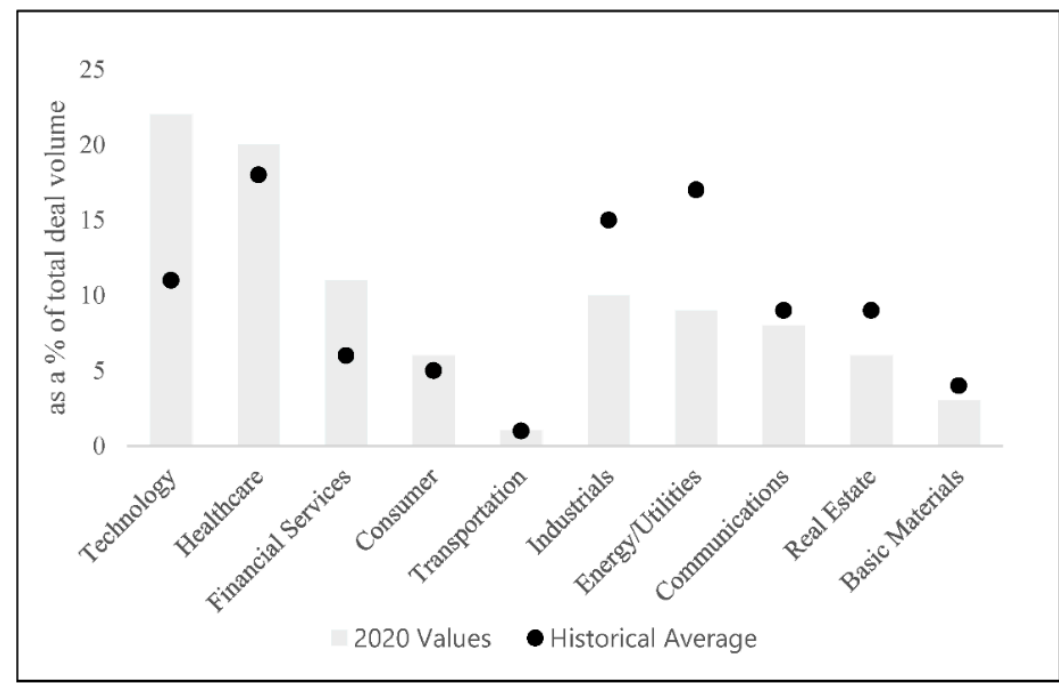

Figure 2. M\&A Activity by Industry (Source: Data collected from Refinitiv). 


\section{Deal size}

The year-over-year change in deal volume decreased by about $7.5 \%$ in 2020 , whereas the total value of transactions decreased by $16 \%$ [9]. More particularly, insights gathered by PwC on the Global M\&A Industry trends, as illustrated in Figure 3, show that despite the sharp decline in the first half of 2020, the global deal value and volume increased by $94 \%$ and $18 \%$ respectively, which were both superior to the last two quarters of 2019 . The number of megadeals in the last two quarters amounted to 56 megadeals in 2020 compared to 27 megadeals in 2019.

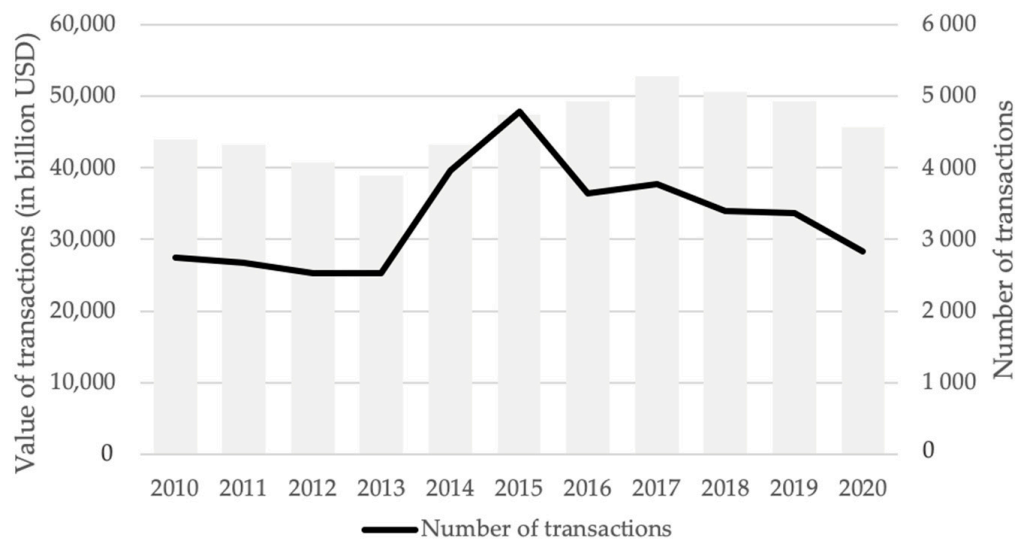

Figure 3. Mergers \& Acquisitions Worldwide (Source: Data collected from IMAA).

As showcased by Figure 4, the surge in deal value may be attributed to an increase in the number of megadeals (that is, deals that are greater than USD 5 billion). Those megadeals occurred more particularly in the technology and telecom sectors where M\&A activity was up in value by $118 \%$ and $300 \%$, respectively. The surge in megadeals in the third and fourth quarter of 2020 exemplifies the ambition of companies to profit from the favorable interest rates and to "scale during the downturn" [10].

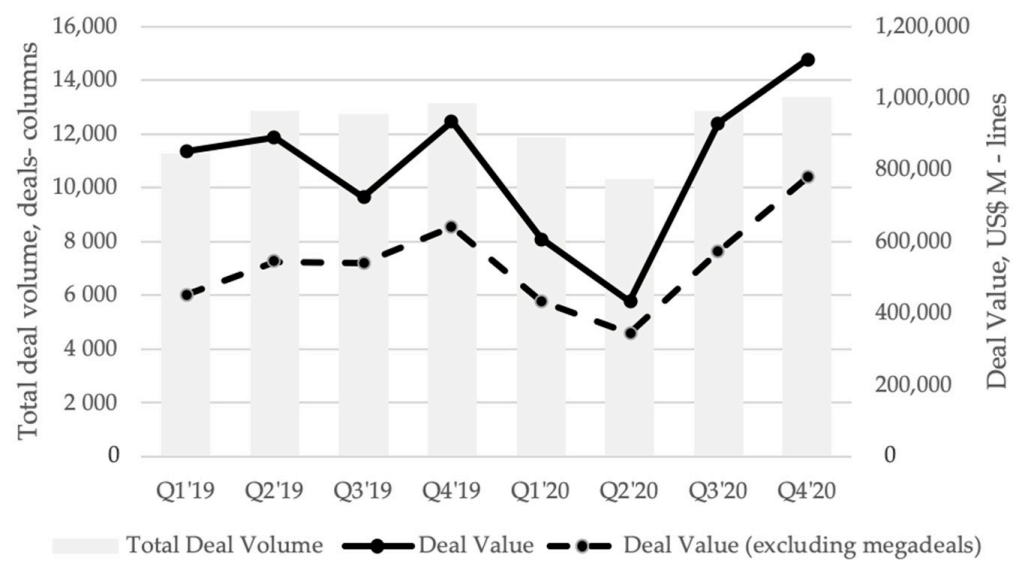

Figure 4. Global Deal Volumes and Values (Source: Data collected from Refinitiv, Dealogic \& PwC Analysis).

\subsection{Impact of COVID-19 on MEA Activity}

The commonality between the previous financial crises and the one that incepted in late 2019 and early 2020 is that they all inflicted unprecedented financial turmoil. As the research presented by Andriuškevičius [11] mentions, events of economic uncertainty highlight the capacity of M\&A activity to create value for companies looking to grow strategically, innovate, and/or adjust in light of changing socio-economic conditions. 
Unlike precedent financial crises, the interruption caused to deal volume during the COVID-19 crisis was not solely a consequence of the downgrading of economic factors. It was more so an amalgam of environmental and financial determinants. Therefore, overnight, unlike other downturns, the industry was forced to transform its strategies, processes, and traditional methodologies to account for the new reality that encompassed more than financial constraints.

\section{Impact on strategic focus}

The pandemic has tested the viability of firms in an evolving competitive landscape where the "essential nature" of the firm, the delivery method of products or services, or the firm's place in the value chain have been reexamined. The virus has thus revealed the weaknesses of corporate structures and presented an opportunity for businesses to transform and innovate, and to realign their strategic paths to address the current mismatch between the firm's value proposition and the evolving needs of its business environment [12].

(i). M\&A to stimulate inorganic growth

In response to the health crisis, there is a group of companies that have looked towards M\&A for the "upgrading and updating of resources and capabilities in a timely manner to avert environmental shift, rendering the current strategy obsolete" [1]. Faced with the unpredictable limitations of the pandemic, corporate executives were compelled to consider more attentively the strategic fit of M\&A, and the capacity of M\&A to stimulate inorganic growth and profitability in a slowing economy. For example, during the pandemic, Well Technologies (a company traded on the Toronto Stock Exchange) completed about 10 acquisitions in 2020 to fulfill their corporate strategy of expanding their market share and product portfolio. Acquisitions such as that of Circle Medical Health in November of 2020 were aimed at growing its operations in the United States, whereas the acquisition of DoctorCare was intended to increase their product offering by expanding direct billing services for doctors.

(ii). Opportunistic M\&A to address future concerns

Many would agree that the COVID-19 pandemic caused companies from all industries to undergo a digital transformation that would have otherwise taken about 10 years. Overnight, businesses were pressed to adopt new business models to adapt to the new social distancing measures. This situation gave organizations an insight as to what their present weaknesses were, and what are the gaps they would need to fill to adapt to the future state of their businesses. Opportunistic companies [13] like Accenture, with strong cash positions, seized the low-interest rate and cheaper valuations to acquire companies that would allow them to acquire proprietary technologies or acquire talent (which was difficult during the pandemic) to stay ahead of the upcoming demands of their clients and employees. Moreover, Accenture, as one of the most acquisitive companies, acquired numerous cybersecurity companies or companies specializing in innovative technologies like blockchain and artificial intelligence to acquire the skills and knowledge that their clients would require in the coming years [14]. Furthermore, in December 2020, Salesforce announced the acquisition of Slack Technologies. The goal of this acquisition was to reinforce Salesforce's ecosystem of software applications by combining the technologies of one of the most advanced enterprise-grade communication software to its enterprise offering, in view of getting ahead of their clients' needs in an all-virtual work environment.

(iii). Corporate restructuring for survival

The EY 2020 Global Corporate Divestment Study [15] illustrated how divestments increase the likelihood of companies' resilience in a slowing economy. For example, following the 2008 downturn, companies who were bold enough to transform their businesses through divestitures had median shareholder returns that were $61.5 \%$ greater than companies that did not divest (see Figure 5: Median change in total shareholder return (2010-2018) for divestments completed in years 2008-2010). Consequently, amid the COVID-19 crisis, companies have once again had recourse to divestitures to raise capital for reinvestment, 
optimize their portfolio, and focus on profitable core operations [16]. For example, in October 2020, IBM announced that it was separating from its core legacy operations to focus on cloud computing services that yield higher margins [17] (Vengattil, 2020). This strategy would imply the creation of a separate entity, $\mathrm{NewCo}$, that would absorb the IT Infrastructure Services Unit of IBM and have a separate managing team. Ergo, we can see that in times of an economic slowdown as was the case in the COVID-19 outbreak, some companies have had to transform their businesses by divesting, whether through a spin-off, split-off, or carve-out to survive.

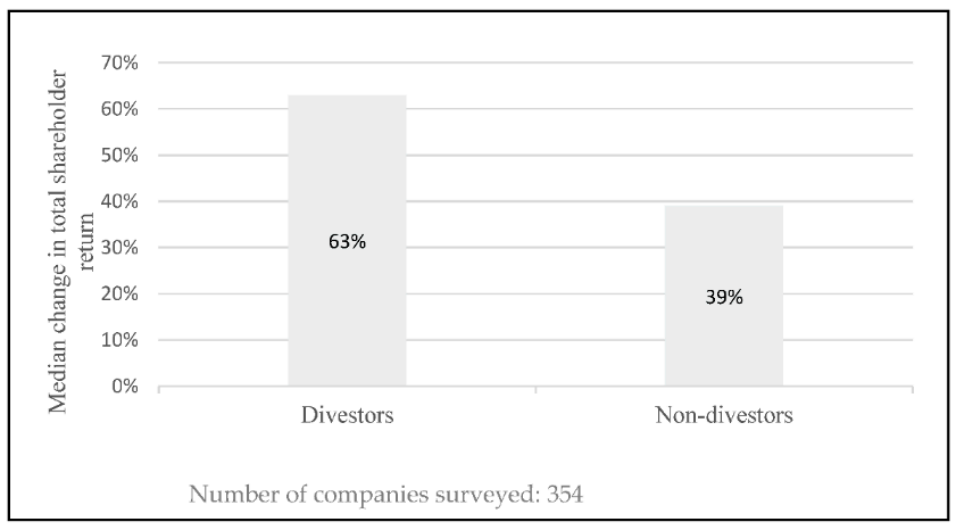

Figure 5. Median change in total shareholder return (2010-2018) for divestments completed in years 2008-2010 (Source: Data collected from EY Analysis, S\&P Capital IQ).

\subsection{Impact of COVID-19 on MEA Process}

In an all-virtual environments, together with uncertain economic expectations, the M\&A process-from planning to deal closure and integration - has had to evolve to match the needs of both buyers and sellers. Figure 6 summarises four distinct processes that have undergone the greatest transformation with the adverse events of the 2020 pandemic.

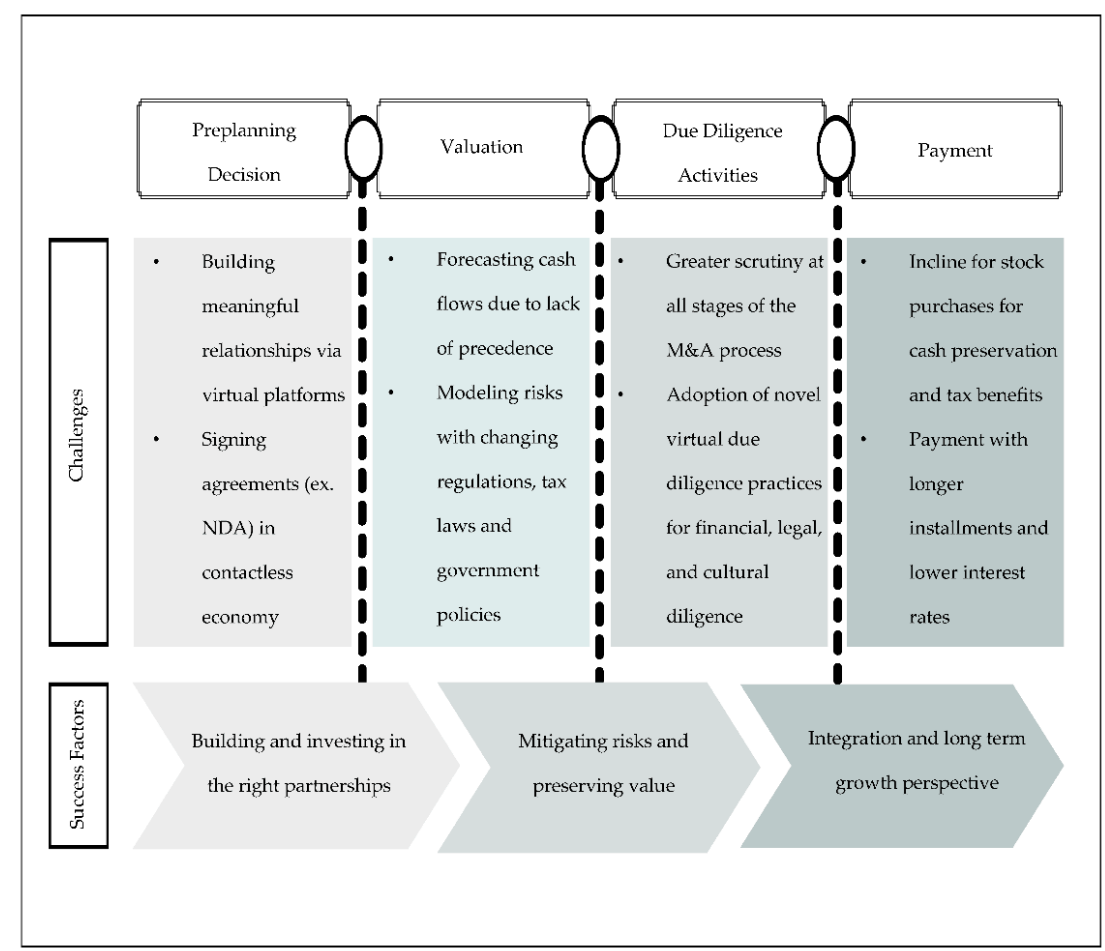

Figure 6. Impact of COVID-19 on the Different Phases of M\&A. 


\section{(i). Preplanning-Relationship building}

Prior to the COVID-19 pandemic, businesses relied heavily on traditional physical experiences; notably, face-to-face meetings, coffee chats, and business conferences to build their deal pipeline, and close deals [18]. With new health guidelines, physical interactions between parties had to be virtualized. One of the major hurdles of having virtual interactions is that it is even more challenging to grasp social cues and to discuss topics that would have otherwise been more fluid in a live setting. Moreover, the contactless economy has given rise to the need for the digitalization of key agreements such as disclosure agreements and non-competing contracts [19]. Subsequently, during the COVID-19 pandemic, there has been the rapid adoption of new tools such as e-signing applications that aim to increase operational agility and reduce the cost of paper and pen transactions [20]. During the pandemic alone, Adobe Sign (an e-signature platform) experienced an increased usage of $200 \%$ by the financial sector [21].

\section{(ii). Valuation gap}

The pandemic's main characteristic is its unpredictability. This key attribute implied that the main economic actors also responded in ways that are not necessarily captured in the math traditionally used in valuation. Therefore, from the onset of the pandemic, the main issue faced by analysts was to accurately forecast the cashflows as pre-existing historical financials did not reflect the short-to-medium-term outlook. Besides, with diverging predictions about the evolution of the pandemic from world leaders, markets acted irrationally, and it became arduous to formulate scenarios. Accordingly, financial leaders had to focus on building models with different durations (18-48 months) to better understand the intrinsic value of firms and to add more flexibility to their models [22]. Stress testing revenues and expenses were also crucial to better define short-term, mid-term, and long-term performances [23]. Additionally, valuation was rendered more complex with government instituted relief loans such as the Paycheck Protection Loan in the United States, as well as significant tax law changes in response to the pandemic [24]. Therefore, in a rapidly evolving environment with no historical precedence, the analysts' job of forecasting cash flows and constructing discount rates that would reflect the reality of the firms required extra diligence. As directed by the dean of valuation, Damodaran, in the context of this global crisis it was thus crucial to "go back to basics and the fundamentals and be willing to live with uncertainty" [25].

(iii). Due diligence

The pandemic exposed the flaws in the supply chains, technological preparedness, and effectiveness of companies in dealing with external shocks. With all those vulnerabilities out in the open, acquirers were compelled to more thoroughly complete due diligence at all stages of the M\&A to have an accurate picture of the impact short-term and long-term impact of the pandemic on the target's viability and resilience [24]. Acquirers and sellers have also been compelled to use more advanced data analysis methods and advanced technologies to consolidate the due diligence process in this virtual and socially distant society. For instance, "P\&G was able to conduct virtual plant tours when it was divesting, with the buyers being able to ask questions of those conducting the tour" [26].

Furthermore, key regulatory institutions running at a lowered capacity have posed additional roadblocks in the due diligence process. For example, "in mid-March, the Department of Justice announced there would be a 30-day delay in addition to the typical three- to six-month due diligence process for it to review mergers in their final stages," [5]. In addition to lengthy processes of financial and legal diligence [27], the pandemic has posed unique challenges in the accurate cultural due diligence of target companies-a crucial step for the proper integration of the target to the acquiring entity. All virtual working environments have presented logistical issues in understanding the organizational dynamic and corporate culture of the target firms; aspects that would, under normal circumstances, be assessed through site visits, employee interviews, and face-to-face interactions [28].

(iv). Payment methods 
An emerging trend during the COVID-19 pandemic is a preference for stock-for-stock purchases. Stock purchases allow acquirers and buyers to go further in the deal process by focusing on relative valuation rather than trying to agree on a purchase price $[29,30]$. Moreover, this strategy was frequent amongst buyers that operate in industries hit hard by the pandemic and where financing was unreachable during the downturn. Furthermore, amidst the persistent uncertainty in the economy, stock-for-stock purchases allowed acquirers to preserve their cash reserves for rainy days. Nonetheless, stock purchases increase the tax breaks for acquirers as opposed to the increased tax liabilities of cash purchases [31].

With conflicting valuations, target companies were more inclined to negotiate payments that would run for an extended duration and with lower interest rates [23]. Acquires armed themselves with more complex post-closure price adjustment mechanisms such as earnouts that are contingent upon achieving specific financial milestones or earnouts that are paid on a sliding scale [24]. Similar to the due diligence process, acquirers and buyers risk aversion was reflected in the payment methods employed.

\subsection{Other Factors Encouraging MEA Activity Amidst the COVID-19 Pandemic}

Inspired by the PESTLE framework created by Francis Aguilar in 1976, Figure 7 explores the microeconomic (internal) and macroeconomic (external) determinants that weigh on the ability and willingness of firms to pursue M\&A transactions. As illustrated, there are microeconomic factors defined by a firm's capacity to complete M\&A during the pandemic, which is characterized by its financial position, and its management team capacity. In terms of macroeconomic factors, there is the health and context of the industry, the overall economic environment, and the socio-political sphere in which the firm operates that encourage or discourage the pursuit of M\&A.

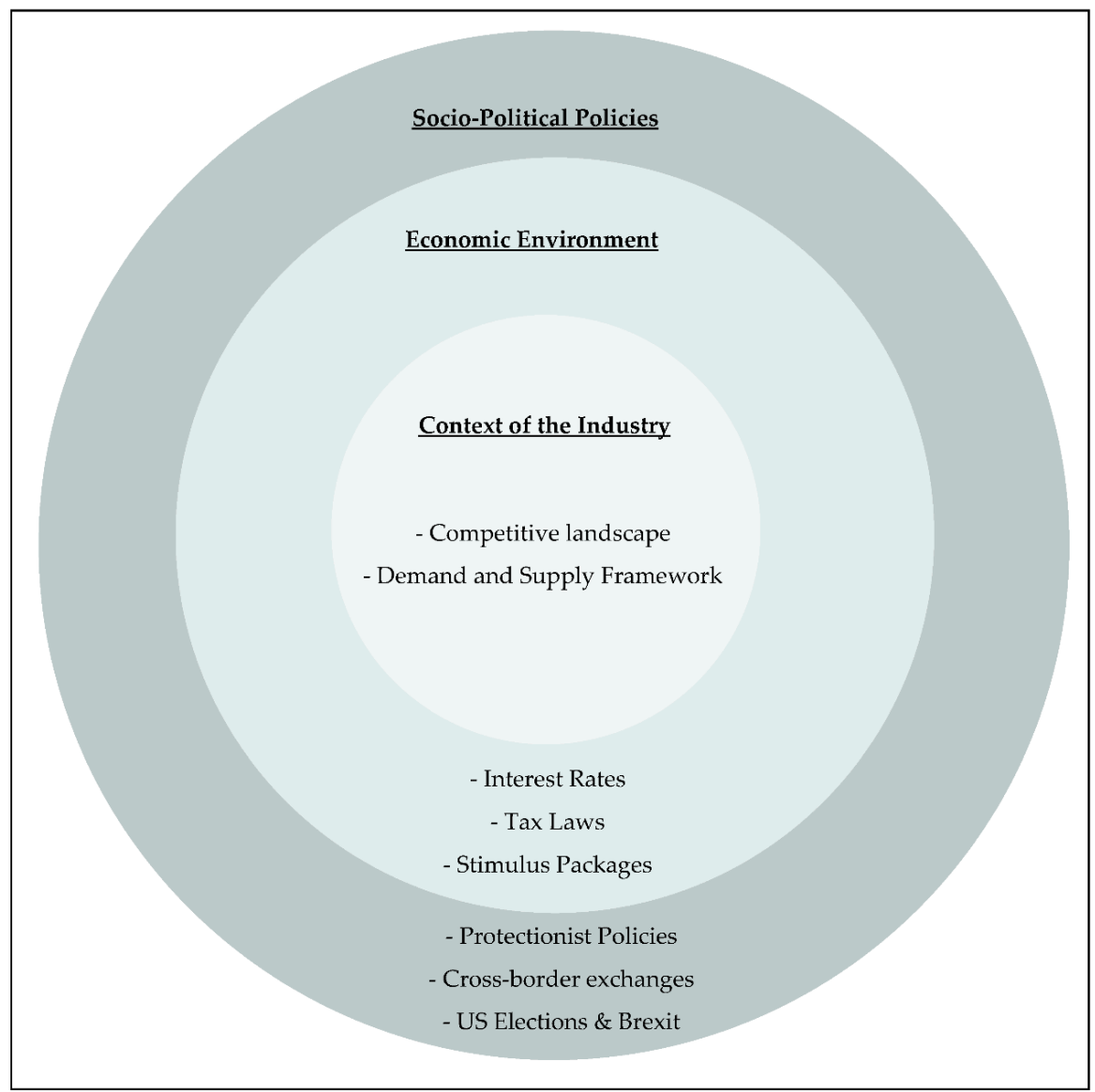

Figure 7. Other Factors Encouraging M\&A Activity Amidst COVID-19 Pandemic. 


\section{Divestitures}

In the short and medium-term, we can expect an increased number of divestitures similar to other economic crises. As BCG's 2020 M\&A Report [32] illustrates; in the first 12 months of the pandemic, many companies looked internally and or into traditional routes such as increasing debt capacity to keep a decent operational capacity. However, in 2021, for many of those companies that are still challenged, management will have recourse to divestments as the market becomes more suitable for M\&A. In a survey conducted by the M\&A Leadership Council, $23 \%$ of the respondents were considering divestitures to raise capital for debt service or to plan for future strategic growth [33]. Divestments may therefore increase in volume a little further into the bust. "The lag occurs because companies first try other actions to cope with the downturn, such as reducing expenditures, obtaining new financing, or exploring strategic options. Moreover, even when they turn to M\&A, they need several weeks to prepare for deal making" [32].

\section{Digitalization of M\&A Activity}

Prior to the pandemic most of the M\&A process relied heavily on physical transactions and relationship-building. Like all industries, the pandemic has forced financial leaders to devise strategies to complete $M \& A$ transactions remotely, from the first introductions to the signing of the deal. With more and more employees having a preference for hybrid work schedules, the M\&A process is deemed to increase its technological tools and capacities to ensure a seamless transition. For example, additional virtual reality capabilities might need to be adopted to facilitate negotiations and due diligence in a virtual world, and more robust cybersecurity will need to be adopted to allow for the safe transmission of sensitive data back and forth between all parties, notably brokers, acquirers, buyers, and regulators. While some physical aspects of the M\&A process might not fully disappear, the 4.0 industrialization of the sector is imperative to keep up with the rapid digitalization of the global society.

\section{Increased focus on scope}

Before the pandemic, many companies had embarked on 4.0 industrialization, with some partially implementing new technology capabilities while others still prioritizing other ongoing concerns over technology. The pandemic has shown the importance of technological and cybersecurity resilience in a hybrid or fully remote workspace. In the long-term industries will see a convergence of industries towards the technology industry. As showcased by a McKinsey survey [34], one of the main priorities of organizations is to ensure the appropriate digital transformation of their firm, as many still find that the changes made are inadequate for survival in the next decade. Therefore, mergers and acquisitions are tools that will be utilized by companies to accelerate the acquisitions of the skills and knowledge, and capture the scope of their technological capabilities.

\section{Cross-border M\&A}

In the medium-long term, we can expect a slight increase in the number of international mergers and acquisitions compared to the slump created by the COVID-19. This trend will be supported by the deployment of vaccines worldwide allowing for a lowering of travel restrictions, greater geopolitical stability with a Biden-Harris government, and Brexit now completed in Europe. Organizations interested in solidifying their supply chains or looking to expand in emerging markets will seize the opportunities presented by greater geopolitical stability and a low-interest market to venture out in other countries to scale their company's operations [35].

Moreover, a lowering of travel restrictions is undoubtedly a factor that would encourage financial leaders who prefer a certain level of physical due diligence to entertain the idea of international acquisitions or mergers. However, the increasing number of protectionist governments worldwide might impose greater regulatory scrutiny and deter cross-border acquisitions. Nonetheless, the vulnerabilities of an interconnected economy might encourage firms to pursue a deglobalization of their operations: companies might want to reinforce their local operations to prevent further halts to their supply chain caused by limitations in cross-border transportation. 


\section{Consolidation of industries}

In the coming years, there will be further consolidation of industries through M\&A as firms look into creating efficiencies through synergies, the lowering of the existing constraints in their respective supply chains, and/or gaining market share. In 2017, "Six companies controlled nearly the entire mixed-media industry. Four airlines controlled $80 \%$ of the market. Five banks controlled $50 \%$ of the industry. Ten companies controlled most of the world's food supply" [36]. Therefore, in vast industries such as the technology and healthcare industries, major consolidations are expected post-pandemic. For instance, in the technology industry, we can expect the execution of conventional consolidations of hardware and software companies, and a new wave of vertical consolidations where technology companies such as the FANGS will acquire companies or merge with companies to create synergies through the acquisition of new proprietary technologies and knowledge of their competitors.

\section{Discussion and Recommendations}

After long-term speculations on the shape of the recovery, it is now clear (in 2021) that the M\&A market had a V-shaped recovery despite the ongoing concerns of the COVID-19 virus and its new strains. Compared to the 2008 economic downturn where there was a lack of liquidity on the markets, in 2021 we can expect the M\&A market to continue on this momentum, as debt and equity financing are readily available and low-interest rates prevail across the globe.

The pandemic has given a glimpse into how private and public institutions and individuals will be called to work together in a virtual world. C-suite executives have gotten a reality check and are now aware of the changes that are required to future-proof their business models. Consequently, the pre-pandemic strategic thinking of firms will need to evolve to match this new growth mindset being displayed in the market. Firms can grow organically through the creation of new products, stronger positioning in expanding markets, and/or increased efficiency in production, or they can grow inorganically through M\&A.

Consequently, firms seeking to grow inorganically through M\&A will need to shift from a defensive strategy to a more offensive approach to capture the disruptions in their sector, but also other market opportunities present outside of their traditional market positioning. Additionally, non-traditional deal-making will also be another way to capture greater opportunities. For instance, alliances, partnerships, joint ventures, or Special Purpose Acquisition Companies (SPACs) are other routes that can be used to restructure businesses for expansive growth. Nonetheless, the post-pandemic business environment will call for more strategic than financially savvy business deals. Financial buyers are those with a greater focus on short-term returns, whereas strategic buyers are those who are interested in acquisitions to generate synergies and long-term growth [24,37-39]. Whatever the route taken by firms, they must anticipate changes in regulations with a change in US administration and an increasing number of protectionist governments across the globe that are looking into supporting their citizen and SMEs in this economic downturn. A more alert forward-looking outlook will insulate companies from unexpected financial or operational impacts that could derail the deal strategy [40].

We should not forget the uprising of the public in 2020 against all social inequality, injustice, and their demand for a more sustainable and equal tomorrow. Therefore, as far as M\&A is concerned it is important to take environmental, social, and governance (ESG) considerations seriously going forward. The profound cultural, physical, and emotional trauma left by the pandemic has compelled consumers to evaluate the ethical, societal, and environmental impact of their consumption decisions [41]. A study performed by Gomes [42] before the pandemic already concluded that strong corporate social responsibility was important in selecting M\&A targets. We can thus assume that in the wake of the pandemic, as the social, environmental, and governance dimensions become more salient, 
acquirers and sellers will have to be more intentional with who they transact with and what are the possible far-reaching implications.

Even though there is currently light at the end of the tunnel with the rollout of vaccines, companies must navigate deals with precaution. Deals are attractive to grow inorganically but it is equally important to invest in their core business to protect their firms against similar future disruptions, namely, solidifying their supply chains and cash-to-cash conversion cycles at all levels of their firms.

Finally, as everyone embraces a digital world, people on all sides of the deal table should embrace innovation and technology while mitigating future cybersecurity risks involved with the integration of technology in the deal process. Physical contact will still be crucial in deal closures; however, the technology will create greater bridges which will trickle down in more benefits in terms of time, productivity, and relationship building for dealmakers.

\section{Conclusions}

In 2021, there is a wave of cautious optimism in the M\&A space. With a shift in priority by firms in response to societal evolution, M\&A can support the evolving enterprise strategies to stimulate growth and scope of companies in the short and medium-term. With an overflow of debt and equity financing, a prevailing seller's market will prevail. The addition of new clauses that account for exogenous shocks, an increased number of baby boomers looking to sell their firms in view of evading the raise in capital gain taxes, and the need to capture technological disruption in all spheres of society will help the M\&A market flourish in 2021 and beyond. However, in the short and medium term, it is crucial for buyers, sellers, and even investment bankers to build their resilience against similar external threats such as the COVID-19 virus. Most importantly, the lesson learned from the pandemic is that organizations can no longer put technological changes on the back burner; rather, it should become one of their priorities. Most importantly, the M\&A sector should have heightened vigilance in regard to scrutiny from lawmakers and ESG considerations.

Unfortunately, with subsequent waves of COVID-19 still impacting countries in varying magnitudes, the research does not fully capture the scope of the impact of the pandemic on the M\&A industry. While the research tries to capture the emerging trends from the start of the pandemic, there is still room for greater statistical and qualitative analyses to examine the long-term impact of this exogeneous event on global M\&A. It would be interesting to further analyze how the most hard-hit industries reconstruct themselves and how M\&A will help shape their medium to long-term goals. In light of geopolitical shifts, it would also be interesting to see how the M\&A market adapts to more scrutiny and more protectionist institutions. Finally, with the momentum given to digital transformation, it would be equally important to explore the challenges of the M\&A industry in terms of adaptation, efficiency, and technology risk. In the next decade, it is clear that the M\&A processes and strategies employed will evolve to match a 4.0 society.

Author Contributions: Conceptualization, C.K. and M.L.S.; methodology, C.K. and M.L.S.; formal analysis, C.K. and M.L.S.; writing-original draft preparation, M.L.S.; writing-review and editing, C.K. and M.L.S.; visualization, C.K. and M.L.S.; supervision, C.K. All authors have read and agreed to the published version of the manuscript.

Funding: This research received no external funding.

Institutional Review Board Statement: Not applicable.

Informed Consent Statement: Not applicable.

Conflicts of Interest: The authors declare no conflict of interest. 


\section{References}

1. Amankwah-Amoah, J.; Khan, Z.; Wood, G. COVID-19 and business failures: The paradoxes of experience, scale, and scope for theory and practice. Eur. Manag. J. 2021, 39, 179-184. [CrossRef]

2. Charlebois, S.; Juhasz, M.; Music, J. Supply Chain Responsiveness to a (Post)-Pandemic Grocery and Food Service E-Commerce Economy: An Exploratory Canadian Case Study. Businesses 2021, 1, 72-90. [CrossRef]

3. Ragazou, K. Business Strategies in HR in Times of Crisis: The Case of Agri-Food Industry in Central Greece. Businesses 2021, 1, 36-50. [CrossRef]

4. Barrafrem, K.; Tinghög, G.; Västfjäll, D. Trust in the government increases financial well-being and general well-being during COVID-19. J. Behav. Exp. Financ. 2021, 31, 100514. [CrossRef]

5. Jacobs, B. COVID-19 Uncertainties Slam Brakes on M\&A Activity. Rochester Bus. J. Available online: https://rbj.net/2020/04/07 / covid-19-uncertainties-slam-brakes-on-ma-activity/ (accessed on 7 April 2021).

6. Macmillan, I.; Purowitz, M. M\&A and COVID-19: Charting New Horizons. Deloitte. Available online: https://www2.deloitte. com/content/dam/Deloitte/global/Documents / About-Deloitte/COVID-19/gx-COVID-19-Mergers-Acquisitions-ChartingNew-Horizons.pdf (accessed on 8 June 2021).

7. Massoudi, A. Global M\&A Recovers on Vaccine Hopes and US Political Stability. Financial Times. Available online: https: / / www.ft.com/content/b1935f10-d1b2-4920-ab76-0a2dff670556 (accessed on 17 November 2020).

8. Strauss, S. Some emerging hypotheses on the economic opportunities and challenges of the post-pandemic world. SSRN Electron. J. 2020. [CrossRef]

9. IMAA. M\&A by Industries. Institute for Mergers, Acquisitions and Alliances (IMAA). 2020. Available online: https://imaainstitute.org/m-and-a-by-industries / (accessed on 30 June 2021).

10. Wittmer, C.; Potter, J.; Marshall, J. Deals Industry Insights. PwC. Available online: https://www.pwc.com/us/en/services/ deals / industry-insights.html (accessed on 30 June 2021).

11. Andriuškevičius, K. Opportunities and challenges of value creation through merger and acquisitions in cyclical economies. Procedia Soc. Behav. Sci. 2015, 213, 764-769. [CrossRef]

12. Seetharaman, P. Business models shifts: Impact of Covid-19. Int. J. Inf. Manag. 2020, 54, 102173. [CrossRef] [PubMed]

13. Baker, H.K.; Dutta, S.; Saadi, S.; Zhu, P. Are good performers bad acquirers? Financ. Manag. 2012, 41, 95-118. [CrossRef]

14. Seal, T. Accenture's Tech Push Makes It World's Most Acquisitive Firm. 2021. Available online: https://www.bloomberg.com/ news / articles/2021-03-02/accenture-s-tech-push-makes-it-world-s-most-acquisitive-company (accessed on 30 June 2021).

15. Jenkinson, D. Global Corporate Divestment I 2020 Study. EY Canada, 2020. Available online: https://www.ey.com/en_ca/ divestment-study (accessed on 30 June 2021).

16. Tze-Liang, C.; Perkins, B.; Murphy, P.; Mills, R. How Portfolio Rebalancing in a Downturn Helps Companies Recover Stronger. EY, 2020. Available online: https:/ / www.ey.com/en_gl/divestment-study/how-portfolio-rebalancing-in-a-downturn-helpscompanies-recover-stronger (accessed on 30 June 2021).

17. Vengattil, M. IBM to Break Up 109-Year Old Company to Focus on Cloud Growth. U.S. Available online: https:/ /www.reuters. com/article/ibm-divestiture-idUSKBN26T1V1 (accessed on 9 October 2020).

18. Deckert, A. Despite global pandemic, M\&A deals were still carried out. Rochester Bus. J. 2021, 36, 11. Available online: https:/ / rbj.net/2021/04/06/despite-global-pandemic-ma-deals-were-still-carried-out/ (accessed on 30 June 2021).

19. Harroch, R.; Lipkin, D.; Smith, R. The Impact of the Coronavirus Crisis on Mergers and Acquisitions. Forbes. Available online: https:/ /www.forbes.com/sites/allbusiness/2020/04/17/impact-of-coronavirus-crisis-on-mergers-and-acquisitions / ?sh=388b2f7a200a (accessed on 17 April 2020).

20. Insights Team. Agree to Automate: How Digitizing the Agreement Process Can Move Your Business Forward. Forbes. Available online: https:/ / www.forbes.com/sites/insights-docusign/2020/10/08/agree-to-automate-how-digitizing-the-agreementprocess-can-move-your-business-forward/?sh=684884d11608 (accessed on 19 November 2020).

21. Abramso, R. E-Signatures Are Still Spreading in the Financial Industry, But Not Really Maturing. Tearsheet. Available online: https:/ / tearsheet.co/modern-banking-experience/e-signatures-are-still-spreading-in-the-financial-industry-but-notreally-growing/ (accessed on 31 March 2021).

22. Macmillan, I.; Sriram, P.; Purowitz, M.; Turner, I. In the Coming Economy, M\&A Strategies Emerging as a Big Deal. Deloitte South Africa. Available online: https:/ / www2.deloitte.com/za/en/pages/finance/articles/cfo-insights-preparing-for-the-nextvirtual-financial-close.html (accessed on 30 June 2021).

23. Patel, A. M\&A activity post COVID-19. Los Angeles Bus. J. 2020, 42, 17.

24. Crowell, B.M. Mergers and Acquisitions during the COVID-19 Pandemic. The Tax Adviser. Available online: https://www. thetaxadviser.com/issues/2020/aug/mergers-acquisitions-covid-19-pandemic.html (accessed on 1 August 2020).

25. Hammond, J.C. Aswath Damodaran on Valuations amid COVID-19: "Go Back to Basics." CFA Institute Enterprising Investor. Available online: https:/ /blogs.cfainstitute.org/investor/2020/05/29/aswath-damodaran-on-valuations-amid-COVID-19-goback-to-basics / (accessed on 17 April 2021).

26. Leach, J.; Kaske, E. How the COVID-19 Pandemic Affects M\&A Transaction Execution. EY-US. Available online: https: //www.ey.com/en_us/strategy-transactions/how-the-covid-19-pandemic-affects-m-a-transaction-execution (accessed on 11 September 2020). 
27. Smith, G.C.; Coy, J.M.; Spieler, A.C. Cross-border transactions, mergers and the inconsistency of international reference points. J. Behav. Exp. Financ. 2019, 22, 14-21. [CrossRef]

28. Siebecker, M.; Lozano, I. Cultural due dilligence and M\&A in the wake of a pandemic. OSLJ Online 2020, 81, 239-252. Available online: http:/ / hdl.handle.net/1811/92248 (accessed on 30 June 2021).

29. Gerritsen, D.F.; Weitzel, U. Security analyst target prices as reference point and takeover completion. J. Behav. Exp. Financ. 2017, 15, 1-14. [CrossRef]

30. Dutta, S.; Saadi, S.; Zhu, P. Does payment method matter in cross-border acquisitions? Int. Rev. Econ. Financ. 2013, 25, 91-107. [CrossRef]

31. Manfredi, R. Gibson Dunn I Stock-for-Stock Mergers during the Coronavirus (COVID-19) Crisis-A Potential Strategic Solution. Gibson Dunn. Available online: https:/ / www.gibsondunn.com/stock-for-stock-mergers-during-the-coronavirus-COVID-19 -crisis-a-potential-strategic-solution/ (accessed on 5 October 2020).

32. Kengelbach, J.; Keienburg, G.; Degen, D.; Söllner, T.; Kashyrkin, A.; Sievers, S. The 2020 M\&A Report: Alternative Deals Gain Traction. BCG Global. Available online: https://www.bcg.com/publications/2020/mergers-acquisitions-report-alternativedeals-gain-traction (accessed on 8 January 2021).

33. Herndon, M.; Bender, J. What M\&A Looks Like During the Pandemic. Harvard Business Review. Available online: https: / / hbr.org/2020/06/what-ma-looks-like-during-the-pandemic (accessed on 10 June 2020).

34. LaBerge, L.; O'Toole, C.; Schneider, J.; Smaje, K. How COVID-19 Has Pushed Companies over the Technology Tipping Point-And Transformed Business Forever. McKinsey \& Company. Available online: https:/ /www.mckinsey.com/businessfunctions / strategy-and-corporate-finance/ our-insights/how-covid-19-has-pushed-companies-over-the-technology-tippingpoint-and-transformed-business-forever (accessed on 18 February 2021).

35. Healy, B. M\&A in 2021: Recovery and Acceleration. Morgan Stanley, 2021. Available online: https://www.morganstanley.com/ ideas/mergers-and-acquisitions-outlook-2021-rebound-acceleration (accessed on 30 June 2021).

36. Adriole, S. Already Too Big to Fail-The Digital Oligarchy Is Alive, Well (\& Growing). Forbes. 2017. Available online: https:/ / www.forbes.com/sites/steveandriole/2017/07/29/already-too-big-to-fail-the-digital-oligarchy-is-alive-wellgrowing/?sh=4721cb3167f5 (accessed on 30 June 2021).

37. André, P.; Ben-Amar, W.; Saadi, S. Family firms and high technology mergers \& acquisitions. J. Manag. Gov. 2014, 18, 129-158.

38. Fernandes, N. How to Capitalize on the Coming M\&A Wave. Harvard Business Review. Available online: https://hbr.org/2021/0 2/how-to-capitalize-on-the-coming-ma-wave (accessed on 3 May 2021).

39. Umar, Z.; Aziz, S.; Tawil, D. The impact of COVID-19 induced panic on the return and volatility of precious metals. J. Behav. Exp. Financ. 2021, 31, 100525. [CrossRef]

40. Levy, M.; Lloyd, M.; Jackson-Moore, W. Global M\&A Industry Trends. PwC, 2020. Available online: https://www.pwc.com/gx/ en/services/deals/trends.html (accessed on 30 June 2021).

41. He, H.; Harris, L. The impact of Covid-19 pandemic on corporate social responsibility and marketing philosophy. J. Bus. Res. 2020, 116, 176-182. [CrossRef] [PubMed]

42. Gomes, M. Does CSR influence M\&A target choices? Financ. Res. Lett. 2019, 30, 153-159. [CrossRef] 